\title{
PERSIMPANGAN PENDIDIKAN ISLAM TRADISIONAL DAN MODERN DI INDONESIA: MENCARI TITIK TEMU
}

\author{
Jalaludin \\ Universitas Islam Negeri (UIN) Sulthan Thaha Saifuddin Jambi \\ Email: jalaludin@uinjambi.ac.id
}

\begin{abstract}
This paper discusses a little about the comparative study between traditional and modern Islamic education in Indonesia which ends at a meeting point between the two. Through the process of reading, analyzing and comparing the opinions of educational leaders in Indonesia it is hoped that it will provide an integrated concept between traditional and modern Islamic education. This paper begins with a discussion of the concepts of traditional and modern education, traditional and modern forms of education that have been implemented so far, the reality of the intersection between traditional and modern education and ends with a new paradigm of Islamic education in future Indonesia. The results showed that the etymology of traditional and modern words are not so contradictory. But if it is related to Islamic education, there will be fundamental differences between traditional education and modern education, especially differences in philosophical views, methodologies and systems in each. The meeting point between the two is that they both recognize the Koran and the Sunnah as basic teachings while the point of difference between the two lies in ijtihad and tajdid.
\end{abstract}

Keywords: Education, Traditional Islamic Education - Modern.

\begin{abstract}
Abstrak
Tulisan ini membahas sedikit tentang kajian komparatif antara pendidikan Islam tradisional dan modern di Indonesia yang berujung pada satu titik temu antara keduanya. Melalui proses membaca, menganalisis dan membandingkan pendapat para tokoh pendidikan di Iindonesia diharapkan akan memberikan sebuah konsep yang terpadu antara pendidikan Islam tradisional dan modern. Tulisan ini diawali dengan pembahasan tentang konsep pendidikan tradisional dan modren, bentuk pendidikan tradisional dan modern yang dilaksanakan selama ini, realita titik temu antara pendidikan tradisional dan modern dan diakhiri dengan paradigma baru pendidikan Islam di Indonesia masa depan. Hasil penelitian menunjukkan bahwa antara kata tradisional dengan modern secara etimologi tidak begitu berlawanan. Tetapi jika dikaitkan dengan pendidikan Islam, akan terdapat perbedaan mendasar antara pendidikan tradisional dengan pendidikan modern, terutama perbedaan pandangan filosofis, metodologi dan sistem pada masing-masingnya. Titik temu antara keduanya
\end{abstract}

Nur El-Islam, Volume 7, Nomor 1, April 2020 
adalah sama-sama mengakui al-Quran dan Sunnah sebagai ajaran dasar sementara titik perbedaan keduanya terletak pada ijtihad dan tajdid.

Kata Kunci: Pendidikan, Pendidikan Islam Tradisional - Modern

\section{A. Pendahuluan \\ 1. Latar Belakang}

Bagi seseorang yang bertekad kuat ingin mengabdikan dan menenggelamkan dirinya di bidang pendidikan lslam, memerlukan pengkajian yang radikal, menyeluruh dan komprehensif. Kajian tersebut juga mencakup problema-problema, sumber-sumber, serta cara pemecahannya. Studi ilmiah yang dimaksud juga harus komprehensif karena secara filosofis pendidikan merupakan kebutuhan masyarakat yang selalu berkembang secara terus menerus. ${ }^{1}$ Karena itu, diskursus tentang perbandingan pendidikan Islam menjadi penting karena luas dan kayanya khazanah pengembangannya yang hingga hari ini telah mencapai lebih dari 14 abad.

Akibat kayanya sistem pendidikan Islam, ternyata telah berimplikasi kepada tidak semua orang dapat memahaminya secara moderat, bahkan telah membawa polemik yang hingga hari ini belum tuntas dan selalu menjadi topik kajian yang menarik. Di antaranya, perbedaan perspektif tentang konsep pendidikan Islam tradisional dan modern di Indonesia. Lebih jauh, dampak dari perbedaan pemahaman tradisonal dan modern ini telah membawa permasalahan ke masyarakat (awam) antara lain: Pertama; Tidak sedikit orang tua yang tidak mau memasukkan anaknya ke pesantren yang dipandang sebagai lembaga pendidikan tradisional yang telah ada sejak zaman dahulu. Pesantren dikenal sebagai sekolahnya orang surau, belajarnya pakai sarung dan peci. jika lulus hanya bisa baca do'a dan jadi imam shalat. Inilah pernyataan dari pengarang buku Tradisonalisme dalam Pendidikan Islam. $^{2}$

${ }^{1}$ Ali Al-Jumbulati, Perbandinggan Pendidikan (terj), (Jakarta: Rineka Cipta, 1994), h. 238.

${ }^{2}$ Imam Bawani, Tradisionalisme dalam Pendidikan Islam, (Surabaya: Al-Ikhlas, 1990), h. 34 . 
Kedua; Munculnya dualisme, dikotomi, serta upaya memarjinalkan sekolah-sekolah agama Islam; madrasah dan pesantren dengan label "tradisi" yang dikonotasikan klasik, kuno, atau jadul. Sebaliknya, sekolah-sekolah umum dikonotasikan sebagai sekolah sekuler, "modern" atau maju. Akar historis dikotomi ini menurut Karen A. Steenbrink sengaja diciptakan oleh penguasa kolonial sejak lama. ${ }^{3}$ Bahkan Mochtar Naim melakukan kritik keras terhadap dualisme pendidikan ini. ${ }^{4}$

Ketiga; Abdurrahman Wahid (Gus Dur) juga tidak luput memberikan pernyataan kontroversial dengan menyebutkan bahwa kehadiran Muhammadiyah telah menawarkan sebuah keyakinan agama yang sama sekali baru di kalangan kaum muslimin di Indonesia, sehingga terjadi perubahan revolusioner yang mendasar, bukan hanya bersifat keagamaan murni belaka...melainkan melimpah ke sektorsektor lain. Gus Dur menilai Muhammadiyah modern dan Nahdhatul Ulama (NU) adalah aliran Ahlussunnah wa al-Jama'ah berpaham tradisional dengan ungkapan selanjutnya; Tradisi merupakan warisan berharga dari masa lampau yang harus dilestarikan sejauh mungkin..., bagi jamaah Ahlussunnah wa al-Jama'ah, pengembangan tradisi harus dilaksanakan dengan jalan menumbuhkan kebanggaan bertradisi,,, . Di pihak lain, kalangan Muhammmadiyah juga mengakui NU itu tradisonal dan Muhammadiyah adalah modern. Ungkapan itu dapat dibaca dari tulisan yang dituangkan oleh A. Malik Padjar tentang Reformasi dan Reorientasi Wawasan Pendidikan Islam: Suatu catatan untuk Muhammadiyah dan NU. ${ }^{6}$

Tiga wacana yang problematik di atas memerlukan tinjauan lebih lanjut khususnya perspektif pendidikan Islam tradisonal dan modern guna menemukan titik temu antara keduanya sehingga

\footnotetext{
${ }^{3}$ Karel A. Steenbrink, Pesantren. Madrasah Sekolah Pendidikan Islam dalam Zaman Modern, (Jakarta: LP3S. 1986), h. 15.

${ }^{4}$ Marwan Saridjo, Bunga Rampai Pendidikan Agama Islam, (Jakarta: Ditjen Binbagais Depag, 1997), h. 1.

${ }^{5}$ Abdurrahman Wahid, Muslim di Tengah Pergumulan, (Jakarta: LP3N (Wahid, 1981), h. 36.

${ }^{6}$ A. Malik Fadjar, Visi Perbandingan Pendidikan Islam, (Jakarta: LP3N, 1988), h. 16.
} 
melahirkan visi baru pendidikan Islam Indonesia. Tuliasan ini akan diawali dengan kajian komparatif antara pendidikan Islam tradisional dan modern di Indonesia.

\section{Identifikasi Masalah}

Adapun yang menjadi identifikasi masalah dalam penelitian ini adalah: 1) perbedaan perspektif tentang konsep pendidikan Islam tradisional dan modern di Indonesia, 2) Munculnya dualisme, dikotomi, serta upaya memarjinalkan sekolah-sekolah agama Islam; madrasah dan pesantren dengan label "tradisi" yang dikonotasikan klasik, kuno, atau jadul. Sebaliknya, sekolah-sekolah umum dikonotasikan sebagai sekolah sekuler, "modern" atau maju.

\section{Teori/Kajian Terdahulu}

Penelitian mengenai persimpangan pendidikan Islam tradisional dan modern ini telah banyak diteliti oleh penulis lain. Beberapa diantaranya adalah: (1) Tabrani ZA dalam bukunya berjudul "Ilmu Pendidikan Islam (Antara Tradisional dan Modern). Tabrani ZA menyatakan bahwa Perubahan yang terjadi dalam kehidupan masyarakat baik sosial maupun kultural, secara makro persoalan yang dihadapi pendidikan Islam adalah bagaimana pendidikan Islam mampu menghadirkan disain atau konstruksi wacana pendidikan Islam yang relevandengan perubahan masyarakat. Kemudian disain wacana pendidikan Islam tersebut dapat dan mampu ditransformasikanatau diproses secara sistematis dalam masyarakat. Persoalan pertama ini lebih bersifat filosofis, yang kedua lebih bersifat metodologis. Pendidikan Islam perlu menghadirkan suatu konstruksi wacana pada dataran filosofis, wacana metodologis, dan juga cara menyampaikan atau mengomunikasikannya. Dalam menghadapi peradaban modern, yang perlu diselesaikan adalah persoalan-persoalan umum internal pendidikan Islam yaitu (1) persoalan dikotomik, (2) tujuan dan fungsi lembaga pendidikan Islam, (3) persoalan kurikulum atau materi. Ketiga persoalan ini saling interdependensi antara satu 
dengan lainnya ${ }^{7}$. (2) Moh. Khoiruddin dalam jurnalnya yang berjudul Pendidikan Islam Tradisional dan Modern menyatakan bahwa Pendidikan Islam seyogyanya harus mampu merubah diri, bukan hanya bersikap mengedepankan ilmu-ilmu agama (ulum al-din) saja, tetapi pendidikan Islam juga harus mampu menjawab tantangan zaman. Tujuan pendidikan Islam seyogyanya tidak hanya bertujuan untuk kebahagiaan ukhrawi saja, tetapi juga harus bertujuan untuk kebahagiaan duniawi. Pendidikan Islam harus mampu memasukkan IPTEK kedalam kurikulum pendidikannya, sehingga peserta didik mampu menguasai IPTEK sebagai bekal mereka untuk menaungi samudra kehidupan. Di sinilah kemudian penting untuk memadukan sistem pendidikan Islam tradisional dengan sistem pendidikan Islam modern. Kedua jenis pendidikan Islam (tradisional dan modern) tetap selalu dibutuhkan ${ }^{8}$.

\section{Metodologi}

Penulis melakukan beberapa tahapan dalam menjawab tujuan penelitian ini, yaitu yang dimulai dari proses membaca, menganalisis dan membandingkan pendapat para tokoh pendidikan di Iindonesia sehingga diharapkan akan memberikan sebuah konsep yang terpadu antara pendidikan Islam tradisional dan modern.

\section{Tujuan Penelitian}

Adapun yang menjadi tujuan dalam penelitian ini adalah membahas tentang kajian komparatif antara pendidikan Islam tradisional dan modern di Indonesia yang berujung pada satu titik temu antara keduanya.

${ }^{7}$ Tabrani ZA, Ilmu Pendidikan Islam (Antara Tradisional dan Modern), (Kuala Lumpur: Al-Jenderami Press, 2009), h.

${ }^{8}$ Moh. Khoiruddin, Pendidikan Islam Tradisional dan Modern dalam Jurnal Tasyri' Vol. 25, No. 2, Oktober 2018, h. 92. 


\section{B. Pembahasan}

1. Tradisional dan Modern: Sebuah Perbandingan

1) Pengertian Tradisional dan Modern

Poerwadarminta menyebutkan bahwa kata tradisi berarti segala sesuatu, prilaku, adat, kepercayaan dan kebiasaan dalam masyarakat secara turun menurun. Sedangkan kata modern berarti mutakhir, terbaru pada zamannya. Kata modernisasi bermakna proses pergeseran sikap dan wawasan sesuai dengan tutntutan masa kekinian. ${ }^{9}$

Dari kata tradisi menjadi kata tradisional, tradisionalis dan tradisionalisme. Tradisonal artinya menurut. adat, turun menurun, yang biasanya digunakan untuk mensifati sesuatu. Kata tradisionalis digunakan sebagai lawan dari kata modern. Istilah tradisionalis sering digunakan untuk menunjuk orang atau kelompok masyarakat yang dengan gigih mempertahankan berbagai tradisi masa lalu dalam prilaku hidup sehari-hari. Di kalangan kaum muslimin Indonesia misalnya NU disebut kaum tradisionalis dan Muhammadiyah dikategorikan kaum modernis, meskipun masih controversial. ${ }^{10}$ Kata modernis secara harfiah berarti kelompok yang mendukung atau melakukan sesuatu dalam proses modernisasi. Kaitannya dengan Islam, istilah modernis sering dipahami berbeda dan dikacaukan dengan istilah lain seperti revivalis, fundamentalis, reformis dan lain sebagainya.

Menurut Fazlur Rahman modernisme Islam yang diperjuangkan kelompok modernis muslim terletak pada penciptaan ikatan-ikatan positif antara pemikiran Qurani dengan pemikiran modern mengenai beberapa persoalan kunci, yang timbul karena dipadukannya beberapa antara lembaga modern dengan orientasi al-Quran tentang moral dan sosial. Upaya intelektual modernis didasarkan atas warisan kebangkitan Islam abad ke-18 dan 19 dipelopori Wahabiyah. Jamaluddin Al-Afgani dan pengikut lainnya. Kelompok modernis

\footnotetext{
${ }^{9}$ Poerwadarminta, Kamus Lengkap Bahasa Indonesia Populer, (Bandung: Ganesha, 1951), h. 881

${ }^{10}$ Deliar Noer, Gerakan Modern Islam di Indonesia 1900-1942, (Jakarta: LP3ES, 1985). h. 241.
} 
berpendapat bahwa al-Quran dan Sunnah merupakan dua faktor yang menentukan dalam Islam, dan bahwa umat muslim berkewajiban mencari pemecahan terhadap masalah-masalah baru melalui ijtihad berdasarkan kedua sumber pokok tersebut. Kelompok penggerak kembali Islam disebut pramodemis, revivalis dan fundamentalis. Tiga ciri khas kelompok modernis menurut Fazlur Rahman adalah: pertama, berusaha menghadapi semua situasi baru dan yakin dapat memecahkannya, kedua, gerakannya bersifat kerakyatan, dan ketiga, melibatkan pemikiran pribadi. ${ }^{11}$

\section{2) Bentuk Pendidikan Tradisional}

Telah disinggung pada bagian awal tulisan bahwa kelompok tradisional, dalam hal ini pendidikan tradisional, didukung atau dimiliki oleh masyarakat tertentu yang cendrung mempertahankan tradisi-tradisi masa lalu. Jika komunitas itu melakukan perubahan atau penyesuaian dengan kondisi kekinian, maka berarti dia meninggalkan baju tradisionalnya. Contoh: di Indonesia dikenal ada pesantren tradisional dan ada pula pesantren modern. Deliar Noer menunjuk NU dan Persatuan Tarbiyah Islamiyah (Perti) sebagai kelompok tradisionalis atau konservatif, meskipun masih berbentuk paradignma kontroversial. ${ }^{12}$ Ciri-ciri pendidikan tradisionalis selanjutnya;

1) Sangat kokoh dan kuat memegang ajaran sufisme. Pemahaman mereka terhadap al-Quran dan Sunnah sering kelihatan kaku dan kurang memperhatikan perkembangan ilmu-ilmu modern. ${ }^{13}$

2) Dalam kaitannya dengan NU khususnya pesantren atau sekolah tradisionalnya menganut filsafat yang mereka klaim sebagai panganut Ahlussunnah Wal Jama'ah dipegang sebagai tradisi filosofisnya dan harus dipertahankan sebagai warisan masa lalu. ${ }^{14}$

${ }^{11}$ H.A.R. Gibb, Aliran-aliran Modern dalam Islam, (.Jakarta: Rajawali, , 1993), h. 51

${ }^{12}$ Deliar Noer, Gerakan Modern Islam, h. 336

${ }^{13}$ Mastuhu, Memberdayakan Sistem Pendidikan Islam, (Jakarta: Logos, 1999), h. 124

${ }^{14}$ Abdurrahman Wahid, Muslim di Tengah, h. 39 
3) Pesantren tradisonal sudah ada sejak zaman para wali di daerah Jawa, sementara kurikulumnya hanya mengajarkan mata pelajaran Agama. ${ }^{15}$

4) Metode belajar sorogan, dimana seorang kiyai duduk melingkar bersama murid-muridnya sambil membawa kitab masingmasing. ${ }^{16}$

5) Sarana dan prasarananya yang sangat sederhana, lingkungan yang kurang ditata sanitasinya, biasanya sekolah tradisional ini di desa, kuat memegang tradisi haul leluhurnya dengan sesajian dan berzanji. bahkan kepeloporan sebuah pesantren tradisional dengan ritus-ritus besar semacam itu (Akbar, 1980: 98). ${ }^{17}$

6) Hubungan Kiyai dengan Santri demikian erat sekali. ${ }^{18}$

\section{3) Bentuk Pendidikan Modern}

Gagasan modernisasi pendidikan Islam mempunyai akar pada gerakan medernisme pemikiran dan institusi secara keseluruhan, sebagai prasyarat bagi kebangkitan kaum Muslim abad modern. Modernisasi juga mempunyai filosofis bahwa menpertahankan kerangka berpikir atau pendidikan tradisional hanya akan memperpanjang nestapa penderitaan kaum Muslimin dalam kancah kemajuan dunia modern.

Modernisasi pendidikan Islam di Indonesia adalah proses multidimensional yang kompleks, Satu sisi modernisasi pendidikan mutlak diperlukan untuk mencapai kemajuan atau pembangunan. Tetapi sisi lain pendidikan juga sering dianggap obyek modernisasi atau ukuran negara terbelakang yang masih memoderisasikan pendidikannya. Padahal fungsi modernisasi pendidikan pada masyarakat maju adalah untuk memberikan kaitan antara anak didik dan lingkungan sosio-

${ }^{15}$ Zakiah Daradjat, Problematika Remaja di Indonesia, (Jakarta: Bulan Bintang, 1978), h. 30

${ }^{16}$ Imam Bawani, Tradisionalisme dalam Pendidikan, h. 104

17 M. Ali Akbar, Perbandingan Hidup Secara Islam dengan Tradisi di Pulau Jawa, (Bandung: AI-Maarif,, 1980), h. 98

18 Kuntowijoyo, Muhammadiyah dalam Perspektif Sejarah. (Yogyakarta: PLP2M, 1985). h. 35 
kulturalnya yang terus berubah. Dalam banyak hal, pendidikan secara sadar digunakan sebagai instrumen untuk perubahan dalam sistem politik dan ekonomi. Untuk mencapai tujuan modernisasi tersebut pendidikan mengalami perubahan fungsional dan antar sistem. ${ }^{19}$ Demikian juga metode, ukuran kelas, administrasi, kurikulum dan sarana prasarana lainnya sebagaimana berikut ini:

Awal kemunculan modernisasi pendidikan Islam di Indonesia berkaitan erat dengan pertumbuhan gagasan modenisasi di kawasan ini. Gagasan modernisasi Islam yang menemukan momentumnya sejak awal abad ke-20, pada lapangan pendidikan modern yang diadopsi dari sistem pendidikan kolonial Belanda. Prakarsa pertama dalam hal ini adalah organisasi-organisasi modernis Islam seperti Jami'at Khair, al-Irsyad, Muhammadiyah dan lain-lain. Muhammadiyah mengadopsi MULO, HIS dan lain-lain di samping membedakan diri dengan memasukkan pendidikan agama ke dalam kurikulumnya. ${ }^{20}$

Keberhasilan Muhammadiyah yang luar biasa terletak dalam kegiatan pendidikannya, baik di kalangan tua maupun pemuda. Sekolah-sekolah Muhammadiyah termasuk beberapa buah yang memakai Bahasa Belanda sebagai bahasa pengantar, mengajarkan silabus modern yang memasukkan pendidikan umum, gaya pendidikan barat dan pendidikan Agama. Termasuk pendidikan agama dengan Bahasa Arab serta Tafsir al-Quran. ${ }^{21}$

Modernisme dan modernisasi pendidikan Islam dilihat dari perspektif perkembangan sosio-kultural, ekonomi dan politik, kelihatannya merupakan suatu keniscayaan. Sistem dan kelembagaan pendidikan tradisonal Islam sulit untuk bisa survive tanpa modernisasi. Seperti digambarkan di atas, modernisasi pendidikan Islam berlangsung menjelang milenium III, nampaknya akan terus berlangsung di masa yang akan datang. Tetapi modernisasi pendidikan Islam tidak pernah sepi dari kritik dan problematik. Salah satu

19 Azyumardi Azra, Pendidikan Islam: Tradisi dan Modernisasi Menuju Milenium Baru, (Jakarta: Legos, 1999), h. 31

${ }^{20}$ Ibid., h. 36

${ }^{21}$ A. Malik Fadjar, Visi Perbandingan Pendidikan, h. 12 
masalah pokok adalah hubungan antara Islam dan modernisme, modernitas dan modernisasi itu sendiri. Memang pada tingkat doktrin hampir seluruh pemikir Islam modern sepakat bahwa pada dasarnya tidak ada pertentangan antara Islam dengan modernisme. Karena sama-sama mengakui al-Quran dan Sunnah sebagai rujukan esensialnya. $^{22}$

Hanya saja, masalahnya adalah sejauh mana modernisme dan modernisasi itu bisa ditoleransi. Sebenarnya ini adalah persoalan klasik. ${ }^{23}$ Namun kalau kita baca beberapa tulisan para pemikir muslim tentang epistimologi pengetahuan dalam Islam, epistimologi theosentrios, Islamisasi Pengetahuan dan sebagainya, Insya Allah pessimisme terhadap modernisasi ini bisa diantisipasi.

\section{Titik Temu Pendidikan Tradisional dan Modern}

Seiring dengan bergulirnya paradigma yang berkembang antara pendidikan Islam modern tradisional, saat ini dirasakan ada keprihatinan yang mendalam tentang dikotomi ilmu agama dan umum. Berbagai istilah yang kurang sedappun muncul seperti pendidikan agama disebut pendidikan tradisional dan sekolah umum disebut pendidikan modern. Bahkan dikotomi itu menghasilkan kesan bahwa pendidikan agama berjalan tanpa iptek dan pendidikan umum hadir tanpa sentuhan agama, kalaupun ada terkadang hanya sebagai pelengkap kurikulum dan tidak masuk UN. ${ }^{24}$

Penggunaan istilah tradisional dan modern yang disalahartikan untuk mendikotomi NU dan Muhammadiyah, Sekolah agama dengan sekolah umum, pada milenium ketiga ini sesungguhnya diperlukan reinterpretasi baru. Karena kedua sistem ini sebenarnya punya titik temu yakni warisan tradisi yang moderat yakni al-Quran, Sunnah dan Ijtihad. Kalangan tradisional mengklaim memegang kuat warisan suci itu, dan telompok modernis justru berjuang untuk kembali kepada alQuran dan Sunnah serta Ijtihad secara murni. Dalam konteks inilah

\footnotetext{
${ }^{22}$ Tadjab, Perbandingan Pendidikan, (Surabaya: Karya Aditama, 1994), h. 55

${ }^{23}$ Mastuhu, Memberdayakan Sistem Pendidikan, h. 1

${ }^{24}$ Ibid., h. 1
} 
diperluka paradigma baru pendidikan Islam. sedangkan prinsip metodologi pendidikan Islam yang menyeluruh, objektif, idealis dan realis, moderat, membuat Pendidikan Islam berada pada posisi antara tradisionalisme dan modernisme. ${ }^{25}$

\section{Paradigma Baru Pendidikan Islam}

Segala usaha untuk mencari paradigma baru pendidikan Islam tidak akan pernah padam dan berhenti sesuai dengan tantangan zaman yang terus berubah dan berkembang. Meskipun demikian, tidak berarti bahwa pemikiran untuk mencari paradigma baru itu bersifat reaktif dan defensive dalam arti menjawab dan membela setelah adanya tantangan. Pencarian paradigma baru haruslah proaktif dan antisipatif, yakni mendahului perkembangan masalah yang akan hadir di masa yang akan datang. Di samping harus mampu mempertahankan nilai-nilai dasar yang benar dan diyakini untuk terus dipelihara dan dikembangkan.

Ada sejumlah permasalahan pendidikan Islam menatap gelombang ketiga yakni postmodernisme. Postmodern menurut pandangan John Naisbitt sebagai "zaman semrawut yang kreatif. Sebagai fenomena global paradoksal, suatu bentuk atau unsur secara kuantitatif mengecil tetapi secara kualitatif semakin mendunia. Itulah wacana baru peradaban manusia (Qutub.

NU dan Muhammadiyah sebagai organisasi keagamaan terbesar di Indonesia, diharapkan mampu mempertahankan gerakan dan peranannya masing-masing, seperti pengalaman sejarah yang panjang masa lalu. Ada dua faktor dominan yang perlu dicatat dari sejarah kepiawaian kedua gerakan Islam itu yang mampu mengkomunikasikan dua hal, yaitu: Pertama; NU dan Muhammadiyah konsisten berpegang teguh pada tradisi keislamannya, berupa keyakinan pada doktrin yang tertuang di dalam al-Quran dan al-Sunnah serta perbedaan paham yang dikembangkan sebagai interpretasi darinya. Kedua; $\mathrm{Nu}$ dan Muhammadiyah memiliki sikap positif terhadap perubahan yang

\footnotetext{
${ }^{25}$ Mumamad Quthb, Sistem Pendidikan Islam (terj.), (Bandung: Al-Ma'arif, 1988),
} h. 24 
terjadi di sekitarnya, sekalipun dalam tingkat responsifitas yang berbeda antara keduanya dalam berbagai kasus. Hal ini tercermin pada langkah-langkahnya yang selalu bersikap adaptif dan akomodatif terhadap persoalan-persoalan yang ada baik bersifat politik, ekonomi, maupun sosial kemasyarakatan. ${ }^{26}$

\section{Kesimpulan}

Mengacu kepada paparan di atas dapat diambil beberapa kesimpulan penting di antaranya:

1) Antara kata tradisional dengan modern secara etimologi tidak begitu berlawanan. Tetapi jika dikaitkan dengan pendidikan Islam, akan terdapat perbedaan mendasar antara pendidikan tradisional dengan pendidikan modern, terutama perbedaan pandangan filosofis, metodologi dan sistem pada masingmasingnya.

2) Titik temu antara keduanya adalah sama-sama mengakui alQuran dan Sunnah sebagai ajaran dasar sementara titik perbedaan keduanya terletak pada ijtihad dan tajdid.

3) Adanya pandangan lama bahwa NU itu tradisional karena pesantrennya dan Muhammadiyah modern karena sekolah umumnya, sesungguhnya kurang tepat karena NU sudah memiliki banyak pondok pesantren modern. Demikian juga Muhammadiyah sudah banyak pondok pesantrennya, disamping memuat lebih banyak pendidikan Agama Islam dibanding dengan sekolah umum lainnya.

4) Diperlukan upaya mengubah kekeliruan pandangan dan interpretasi masyarakat tentang sekolah agama adalah tradisional sementara sekolah umum itu modern. Termasuk menghilangkan dualisme, dikotomi atau sikap diskriminatif terhadap Pendidikan Islam itu sendiri.

5) Adanya paradigma baru dalam pemberdayaan pendidikan Islam yang dimulai dengan dimulainya reinterpretasi epistimologi ilmu dalam Islam, islamisasi pengetahuan, rekonseptualisasi

${ }^{26}$ A. Malik Fadjar, Visi Perbandingan Pendidikan, h. 15. 
pendidikan Islam dan pemikiran postmodernisme, membuktikan. bahwa proses perubahan akan terus berkembang dan tidak berhenti pada proses tradisi modern saja. Gerakan pemikiran ini perlu didukung oleh para inteletual muda sesuai dengan kontek zamannya, sehingga pendidikan Islam tidak dipahami secara parsial.

\section{Daftar Pustaka}

Abdurrahman Wahid. Muslim di Tengah Pergumulan. Jakarta: LP3N. 1981

Ali Al-Jumbulati. Perbandinggan Pendidikan, terj. Jakarta: Rineka Cipta. 1994.

A.Malik Fadjar. Visi Perbandingan Pendidikan Islam, Jakarta: LP3N. 1998.

Azyumardi Azra. Pendidikan Islam: Tradisi dan Modernisasi Menuju Milenium. Baru, Jakarta: Legos. 1999.

Deliar Noer. Gerakan Modern Islam di Indonesia 1900-1942. Jakarta: LP3ES. 1985.

H.A.R. Gibb. Aliran-aliran Modern dalam Islam. Jakarta: Rajawali. 1993

Imam Bawani. Tradisionalisme dalam Pendidikan Islam. Surabaya: AlIkhlas. 1990.

Karel A. Steenbrink. Pesantren. Madrasah Sekolah Pendidikan Islam dalam Zaman Modern. Jakarta: LP3S. 1986.

Kuntowijoyo. Muhammadiyah dalam Perspektif Sejarah. Yogyakarta: PLP2M. 1985.

Marwan Saridjo. Bunga Rampai Pendidikan Agama Islam. Jakarta: Ditjen Binbagais Depag. 1997.

Mastuhu. Memberdayakan Sistem Pendidikan Islam. Jakarta: Logos. 1980. 
M. Ali Akbar. Perbandingan Hidup Secara Islam dengan Tradisi di Pulau Jawa. Bandung: AI-Maarif. 1980.

Moh. Khoiruddin, Pendidikan Islam Tradisional dan Modern dalam Jurnal Tasyri' Vol. 25, No. 2, Oktober 2018.

Mumamad Quthb. Sistem Pendidikan Islam (terj). Bandung: Al-Ma'arif. 1988.

Poerwadarminta. Kamus Lengkap Bahasa Indonesia Populer. Bandung: Ganesha. 1985.

Tabrani ZA, Ilmu Pendidikan Islam (Antara Tradisional dan Modern), Kuala Lumpur: Al-Jenderami Press, 2009.

Tadjab. Perbandingan Pendidikan. Surabaya: Karya Aditama. 1994.

Zakiah Daradjat. Problematika Remaja di Indonesia. Jakarta: Bulan Bintang. 1978. 